\title{
Handwriting as a means of Cultural Identity
}

\author{
Anup Kumar Kapoor* and Monika Saini \\ Department of Anthropology, UGC-Senior Research Fellow, India
}

Submission: April 19, 2017; Published: April 27, 2017

*Corresponding author: Anup Kumar Kapoor, Department of Anthropology, UGC-Senior Research Fellow, University of Delhi, Delhi-110007, India, Tel: 09910544142, Email: anupkapoor46@rediffmail.com; mini.1901@yahoo.com

\section{Opinion}

The uniqueness of handwriting is based on the discriminating elements of writing which are the clear manifestations of writing habits. These writing habits are greatly influenced and shaped by the culture and environment of a writer as handwriting is an acquired skill and environment is the matrix from which this art is acquired and cultivated [1]. The development of handwriting is complex which in part is culture dependent, and culture differs with locales and undergoes constant changes. Handwriting is a fine motor skill and teachings of the motor preliminaries (such as regularity and neatness, the introduction of cultural biases such as slant, counter clockwise rotations, left to right transport, posture and grasp) of writing varies from culture to culture. It can also be defined as a culture-bound activity, where many aspects of a language are greatly influenced by the culture of an individual. Writing is a potent and conventional system of symbols, marks and signs that encodes the utterances of a language. Cultural differences in verbal expression lead to distinctive pattern of native languages. Cheng et al. [2] investigated the impact of native language writing system on English handwriting and found the uniqueness in English handwriting characteristics peculiar to the ethnic origin of the writers.

Culture also plays a crucial role in influencing the cognitive development of a child and this development varies greatly from one culture to the other culture. The way in which a child learns the letter formation during the initial stage of handwriting development is primarily a function of the cultural environment in which he is reared. During childhood, a child remains under the influence of his family members, relatives, cultural peers and teachers which leads to the transmission of graphical skills (i.e. pencil grasp, sitting posture, paper position etc.) vertically, horizontally and obliquely in a population group. Saida and Miyashita [3] compared the fine motor skills of Japanese and British children and found that sequential development of the techniques for holding and moving writing implements was universal among both the groups, but the children progressed from simple to dynamic tripod stages at different stages. (Japanese 35 months and British 48 months) It was speculated that the dynamic tripod development of Japanese children may have been enhanced by cultural differences. In Japan, children are taught to use chopsticks at an early age and therefore exercise their fine motor skills. It has also been found that different ethnic groups adopt different sitting postures and lifestyle [4] that lead to differences in their motor development. According to Super [5] Kipsigis infants from Western Kenya (Africa) were exposed to cultural practices that encourage sitting upright, infants were set down in a special hole in the ground that had been made to help support their backs or blankets were nestled around them. As a likely result of these cultural practices, infants in the Kipsigis culture learned to sit earlier than urban white infants in the USA, where such sitting-ritual was not practiced.

India represents a creative burst of culture which is reflected in different religions, traditions and languages. It consists of multiple regional ethno-linguistic groups that have diverse socio-cultural structure and background. Saini [6] studied the variations in handwriting features among different ethnic groups of India and found that some of the basic characteristics of handwriting follow patterns that are prevalent in a particular culture and environment. It was also stated in this study that "In a population group, people share common cultural and environmental traits that lead to a certain degree of similarity in their cognition and learning behaviours. Being a neuromuscular activity, handwriting relates the cognitive aspects of the brain with the muscular movements. Thus it becomes likely that a certain degree of commonness exist in the handwriting features of the people of the same population group." Few researches had been conducted in the past to identify some of the distinctive features of handwriting that are reflective or representative of a particular ethnic group of writers. Out of these works, a couple of studies took quantitative approach to statistically examine the observed handwriting characteristics. These findings and observations could be of great help to anthropological and forensic science community in the determination of cultural and ethnic origin of a writer based on their peculiar handwriting features [7]. 


\section{References}

1. Monika Saini, AK Kapoor (2015a) Impact of Heredity and Environment in Familial Similarity of Handwriting. IJCER 4(1): 1-10.

2. Cheng N, Lee GK, Yap BS, Lee LT, Tan SK, et al. (2005) Investigation of class characteristics in English handwriting of the three main racial groups: Chinese, Malay and Indian in Singapore. J Forensic Sci 50(1): 177-84.

3. Y Saida, M Miyashita (1979) Development of fine motor skill in children: Manipulation of a pencil in young children aged 2 to 6 years old. Journal of Human Movement Studies 5(2): 104-113.
4. Mullaji AB, Sharma AK, Marawar SV, Kohli AF (2008) Tibial torsion in non-arthritic Indian adults: a computer tomography study of 100 limbs. Indian J orthop 42(3): 309-313.

5. Super CM (1976) Environmental effects on motor development: The case of African infant precocity. Dev Med Child Neurol 18(5): 561-567.

6. Saini M (2016) Handwriting variations among Indian Population Unpublished Thesis, University of Delhi, India.

7. Huber RA, Headrick AM (1999) Handwriting identification: facts and fundamentals. CRC press, USA, pp. 87-139.

\section{Your next submission with Juniper Publishers} will reach you the below assets

- Quality Editorial service

- Swift Peer Review

- Reprints availability

- E-prints Service

- Manuscript Podcast for convenient understanding

- Global attainment for your research

- Manuscript accessibility in different formats

(Pdf, E-pub, Full Text, Audio)

- Unceasing customer service

Track the below URL for one-step submission https://juniperpublishers.com/online-submission.php 